\title{
Farm worker households in Wonorejo Village, Baluran National Park: socio-demographic characteristics and economic assets
}

\author{
Ratri Purnama Dewi ${ }^{*}$, Monita Deka Martiwi ${ }^{1}$, Yolanda Fikrina Aziza ${ }^{1}$, Ratih Fitria Putri $^{1}$, Sri Rahayu Budiani ${ }^{1}$, \\ and Abraham Cardénas Tristan ${ }^{2}$ \\ ${ }^{1}$ Department of Environmental Geography, Faculty of Geography, Universitas Gadjah Mada, Indonesia \\ ${ }^{2}$ Geomatics Engineering, Faculty of Engineering, San Luis Potosi Autonomous University, México
}

\begin{abstract}
Wonorejo is one of the village near Baluran National Park, East Java that dominated by farm workers. The total farm workers in Wonorejo Village up to $45 \%$ by 2018 . We know that farm workers are vulnerable groups which have high risk in poverty. But, these groups actually exist in the village. The purpose of this study is to describe socio-demographic characteristics and economic assets of farm worker households in Wonorejo Village, Baluran National Park, East Java. We used primary data with households survey and descriptive quantitative method of analysis. According to social characteristics it is known that the most of household heads of farm workers in Wonorejo Village did not finish primary school (46\%) and only $65 \%$ of farm workers were all members in healthy condition. According to demographic characteristics, most of farm worker households were headed by male and the number of family members was quite diverse, the average age of farm workers more than 64 years. The result also showed that savings were the one of farm workers strategy for survival.
\end{abstract}

Keywords: Farm worker households, socio-demographic characteristics, economic assets, survival strategy

\section{Introduction}

Wonorejo Village is part of the Baluran National Park, located in East Java Province. The village is adjacent to the Baluran National Park in the north and west, Bali Strait in the east, and Banyuwangi Regency in the south (Figure 1).The total area of Wonorejo is $239,19 \mathrm{~km}^{2}$ [1] dominated by vegetation coverage in the form of forest and agricultural land. Baluran Forest is a part of Baluran National Park, used by some people of Wonorejo to get income through harvesting forest products till nowadays. However, most people actually work as farm worker because of limitation in the forest harvesting activity by Regulation of the Minister of Environment and Forestry of the Republic of Indonesia Number P.43/MENLHK/SETJEN/KUM.1/6/2017.

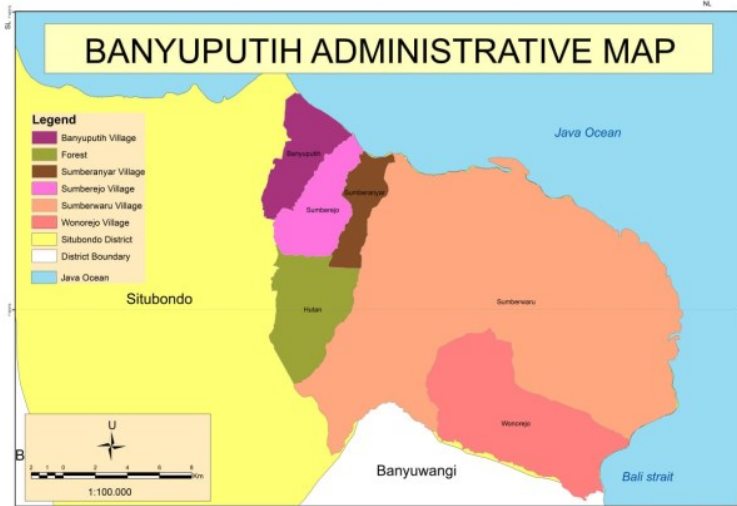

Fig.1. Banyuputih Administrative Map

Farm worker is the majority livelihood in Wonorejo Village. Figure 2 shows that $53 \%$ of population in Wonorejo Village worked as farm worker [2]. The trend of farm workers decreased from 2014 until 2018. But, the percentage value remains large every year (Figure 3 ). Previous research shown that the average of farm workers have a low income [3]. However, the people of Wonorejo Village were actually depend on farm worker as a livelihood they had. 


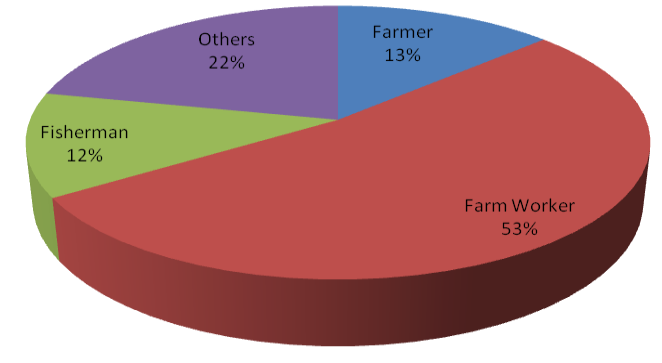

Fig.2. Percentage of population by livelihood in Wonorejo Village by 2018

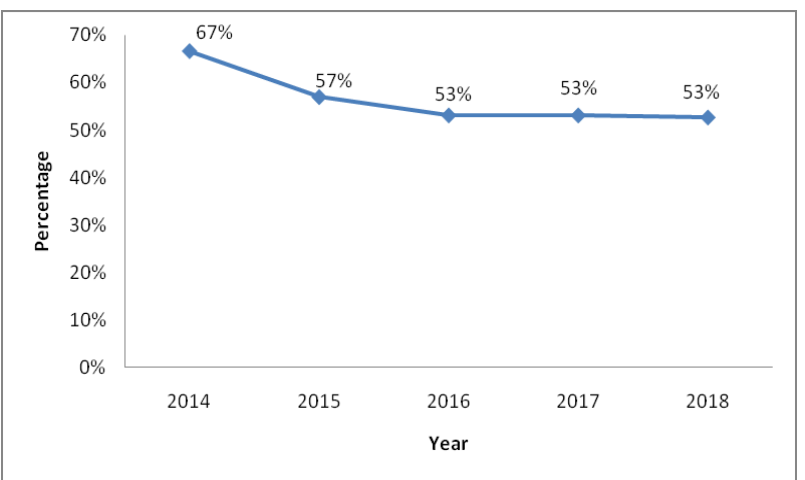

Fig.3. Trend of Farm Workers in Wonorejo Village by 2018

The type of agricultural land in Wonorejo Village is wetland with paddy crops as a major. This is unrelated to the climate conditions around Baluran National Park that has dry climate with temperatures between $27.2^{\circ} \mathrm{C}$ $30.9^{\circ} \mathrm{C}$ and humidity is $77 \%$, so not all plants can grow in this area [4]. Data from BPS shown that irrigation technique had been applied in there. Although Wonorejo's people still working as farm workers, they can survive in economy limited condition. This is why researcher were interested to study farm workers in Wonorejo Village with the detailed purpose is to describe socio-demographic characteristics and economic assets of farm worker households.

\section{Method}

This research used primary data through survey method. We conducted a survey of 76 farm workers from 353 total population in Wonorejo Village by October 2019. The sampling method in this study is using simple random technique. The calculation used to determine the number of samples is the Krecjie-Morgan formula with a confidence level of $90 \%$ :

$$
\mathrm{n}=[3,841 \times N(0,5 \times 0,5)] /\left[(N 1) 0,10^{2}+3,841(0,5 \times 0,5)\right]
$$

The simple random sampling is selected because of the population homogeneity assumption by researchers [5]. Additionally, the confidence level of $90 \%$ we used based on the time limited of survey.

There were four hamlets in Wonorejo Village namely Randuagung, Kendal, Jelun, and Pandean. The number of samples for each hamlets were 14, 20, 36, and 6 samples. The results of the households survey then processed using SPSS software and analyzed using descriptive statistics.

\section{Results and discussions}

Farm workers as one of the agricultural sectors whose conditions need to get special attention so that research was carried out related to the lives of farm workers. The condition of each region will affect the farm workers in the process of farming and obtain a decent living. The life of farm workers is also influenced by various interrelated aspects and tends to affect the level of welfare.

This research was conducted to see and understand the livelihood conditions of farm workers in Wonorejo Village as an area adjacent to Baluran National Park. The discussion that will be presented includes the social characteristics of farm workers, demographic characteristics, and economic assets. This has a bearing in influencing the welfare of farm workers who tend to be in the middle to lower levels.

\subsection{Characteristics of Farm Worker Households}

The social characteristics of farm worker households can be seen from the education and health aspects. This study used the head of the farm worker households as the object of research (sample). In terms of education, the heads of the farm worker households in Wonorejo Village were classified as having a low level of education (Figure 4).

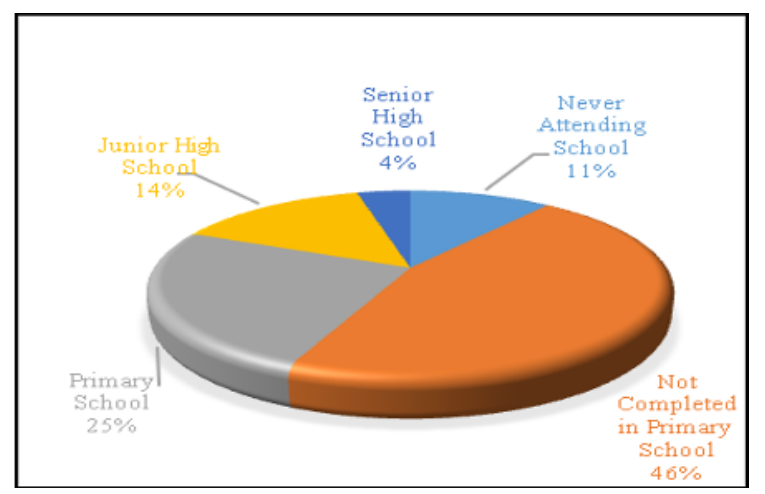

Fig.4. Percentage of Head's Education Level of Farm Worker Households in Wonorejo Village

Most of the heads of farm worker households in Wonorejo Village did not finish elementary school, which was $46 \%$. As for those who graduated from elementary school by $25 \%$, junior high school graduates by $14 \%$, and high school graduates by $4 \%$. Ironically, there are also many heads of farm worker households in Wonorejo village who have never attended school, which is $11 \%$. This fact showed that farm workers generally have low education with the highest grade being elementary school graduates and a small proportion following further education. Research on migrant farm workers in Latina, United State showed that more than one-third of young workers were school 
dropouts and $17 \%$ of them attended school at a lower class level than peers [6].

The second social characteristic of farm worker households is health aspects. Beside education, health aspects also have contribution to the regional development [7]. People who have good quality in their health will improve their productivity and lead the high income.

The health condition of farm worker households can be seen from the presence or absence of household members who were experiencing pain during the survey. Figure 5 showed that the health level of household members of farm workers were quite low. Only $65 \%$ of farm worker households were all members in healthy condition. This condition also exacerbated by the low ownership of health insurance for each household members of the farm workers. Only around 57,9\% of farm worker households have health insurance.

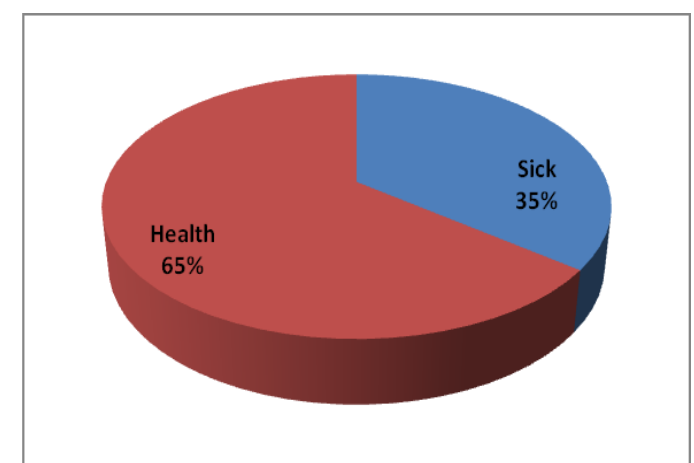

Fig.5. Percentage of Farm Worker Households by Health Status in Wonorejo Village

\subsection{Demographic Characteristics of Farm Worker Households}

Most of the heads of farm worker households in Wonorejo Village were male. Results of the study indicated that there were only $8 \%$ of female-headed households of farm workers in Wonorejo Village (Figure 6). Female-headed households are households that did not have family members with husband or father status.

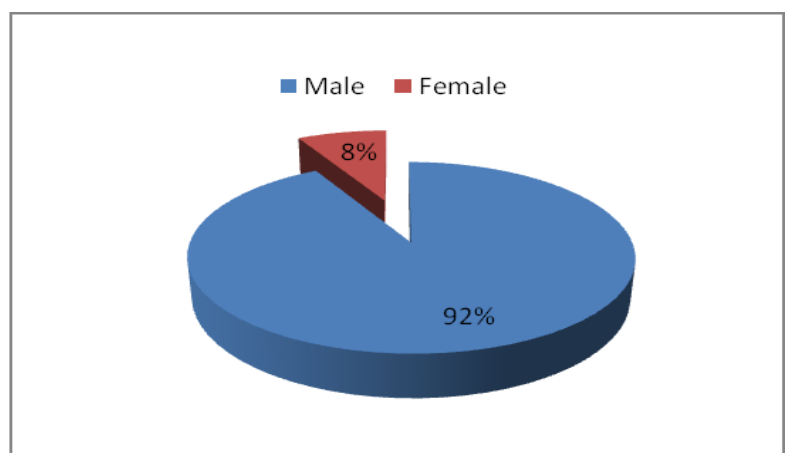

Fig.6. Percentage of Farm Worker Household's Head by Sex in Wonorejo Village

Most of household's heads of farm workers in Wonorejo Village were more than 64 years old by $28.95 \%$ (Figure 7). This fact showed that farm workers in Wonorejo Village were carried out by those who were actually an elderly group. The age range of farm worker household's heads had been started from 30 years and over. This showed that farm workers were actually adult population's job in Wonorejo Village, even closed to the older people.

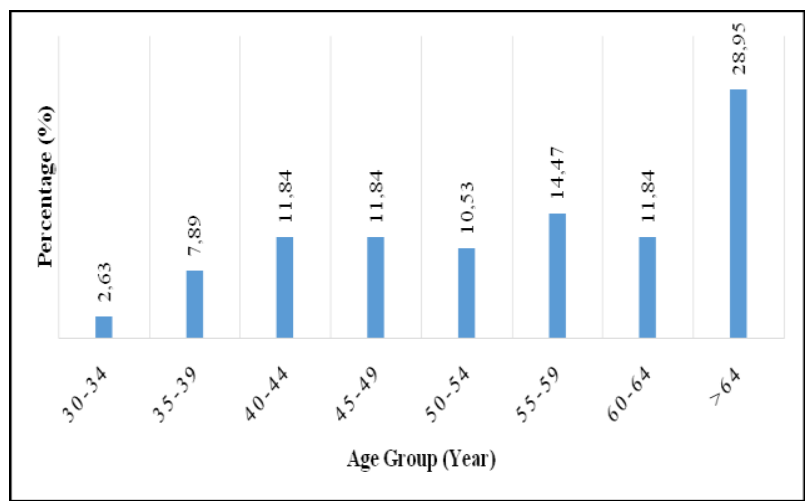

Fig.7. Percentage of Farm Worker Household's Head by Age in Wonorejo Village

The number of household's members of farm workers in Wonorejo Village were quite diverse, ranging from one until four peoples and even more. Figure 8 showed that $21 \%$ of household's members of farm worker in Wonorejo Village numbered more than four peoples. Data from SUSENAS (Survei Sosial Ekonomi Nasional) or National Survey's of Socio-Economic Condition of Indonesia showed that poor households were dominated by five members while non-poor households range between three and four [8,9]. This indicates that the greater number of household members were more likely lived in the poor condition. Republic of Indonesia's Regulation Number 87/2014 concerning on family planning have a superior program with the motto "Two Children Enough", so that one household only consisting of father, mother, and two childrens.

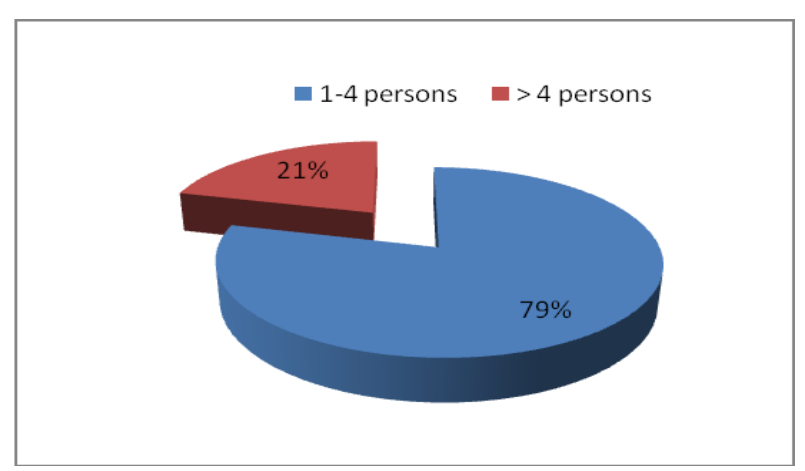

Fig.8. Percentage of Total Household's Members of Farm Workers in Wonorejo Village

\subsection{Farm Worker Economic Assets}

Economic aspect is currently a very important issue in order to find out the adequacy of life needs in community group. Financial assets are fiscal parameters or the ability of the community to allocate a number of assets [10]. Financial also shows the sources of income obtained by a group of peoples. Another definition of finance is the amount of money or assets that have 
economic value which is collected or saved for future investment by a household [11].

Figure 9 showed that farm worker households in Wonorejo Village had enough savings by $80,30 \%$. This fact indicates that farm worker households have had high investment awareness. Organizing income is a way to obtain effective steps for comfort in the following days. The use of appropriate savings can provide future benefits and the most important factor in financial health in the household, especially in future financial payments and emergencies [12].

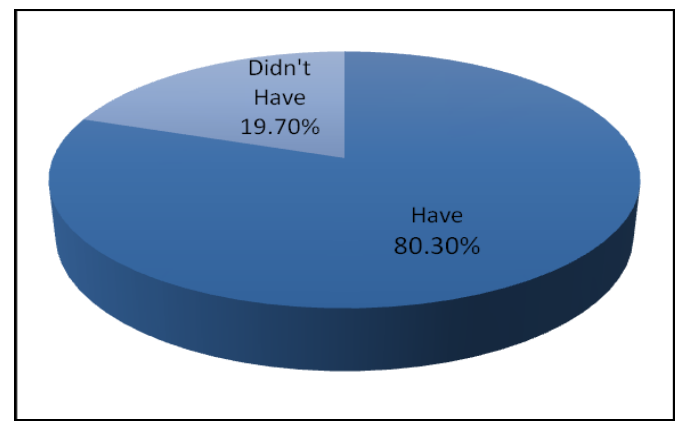

Fig.9. Percentage of Saving Ownership in Wonorejo Village

Farm worker households in Wonorejo Village have had various types of savings, both in money and nonmoney forms. Figure 10 showed the proportion of savings types held by farm workers. More than $50 \%$ of farm worker households had savings in the form of livestocks. There were mostly in the form of chickens or poultry, some goats, and the rarest of cows. This was possible because to buy a cow or bull requires a large capital and the more energy of maintenance and foods.

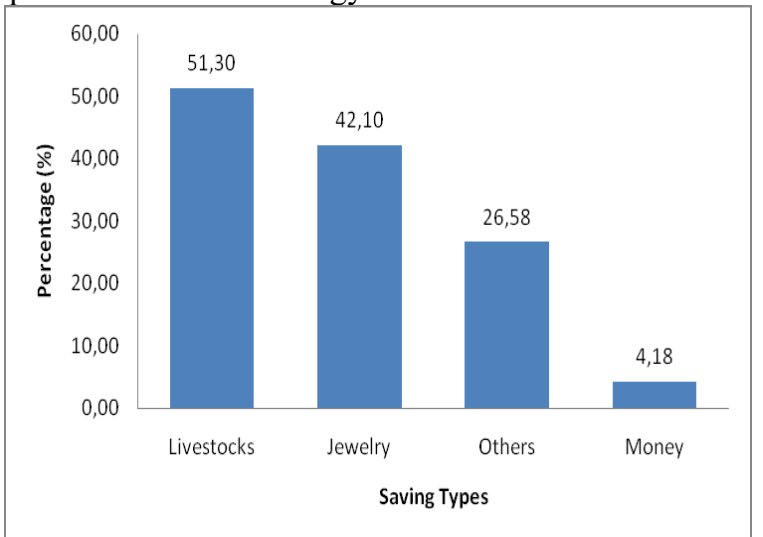

Fig.10. Percentage of Saving Types of Farm Worker Households in Wonorejo Village

Another type of savings that widely owned by farm workers is jewelry $(42,10 \%)$, both stored and worn. The numbers of jewelry saving ownership became high because of most jewelry worn by women during the survey conducted.

Farm workers who had savings in the form of money were only $4,18 \%$. They claimed that they didn't have money to save. The money earned from primary work was only enough to fulfilled primary needs, even not enough. Especially when there was a sudden needs, farm workers didn't have opportunity to set aside their money because of emptiness residual money.
Apart from savings, the farm worker household's financial sources was came from debts. Most of farm worker households had both savings and debts. Debts ownership is one of the steps or efforts used by farm worker households in Wonorejo Village to fulfilled their needs. Needs related to large or sudden expenditures that cause immediately fulfilled by farm workers.

Figure 11 showed that more than $50 \%$ of farm worker households in Wonorejo Village had debts. The sources of debts was vary from banks to neighbors and relatives. The largest percentage of debt sources were from banks and from relatives/neighbors (Figure 12).

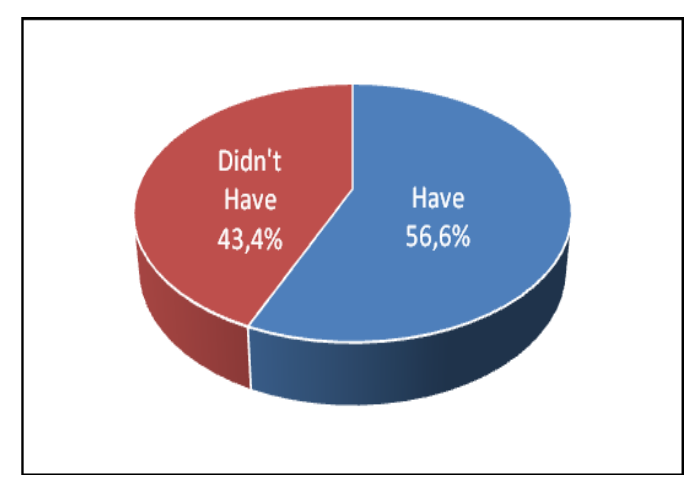

Fig.11. Percentage of Debts Ownership in Wonorejo Village

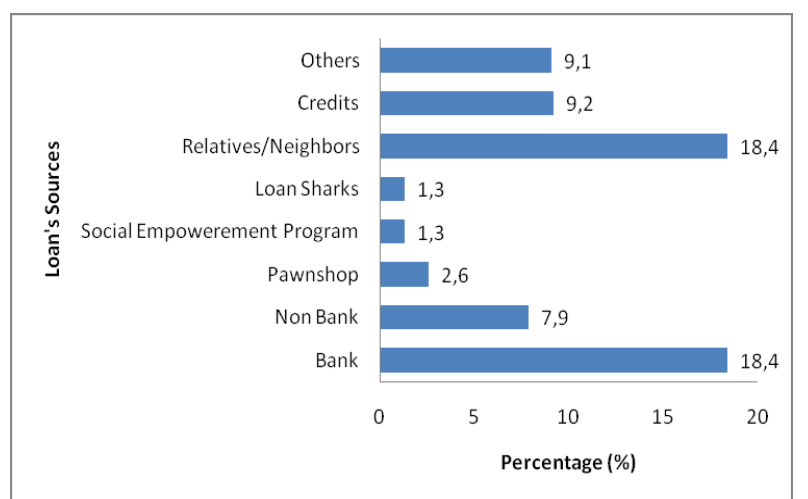

Fig.12. Percentage of Debt Sources of Farm Worker Households in Wonorejo Village

Compared to other sources, proportion of debts at banks and relatives/neighbors were similar and higher. Debts at banks generally require collateral which is adjusted to the amount of money borrowed [13]. Bank as a clear and structured source of debts have operational standards for lending so that borrower will be more orderly and secure. The use of collateral in bank showed that the farm worker households had valuable goods and large quantities of debts. Farm worker households that had debts in bank assumed that they were well informed and have good access to financial resources.

While lending to family, relatives, neighbors, or friends, assumed that farm worker households was looking for own security in debt. Lending at these sources generally doesn't require collateral and only based on mutual trust. These lending activity can't be done in large amounts and over a long period of time because of mutual discomfort with others. Therefore, this type of debt source tends to be safe and not burdensome. 
Percentage of farm worker households that had debts in other sources were less than $10 \%$. Some people still rely on other sources such as pawnshops, private programs, loan sharks, credits, and others. These sources generally have large interest rates and tend to be firm. Lending at these sources are immediate and can lend in large amounts. However, the risk obtained is quite dangerous because the repayment of debt can increase due to the large interest. In addition, when the debts can't be returned, both collateral and non-collateral can be confiscated suddenly.

Results of the cross tabulation showed that farm worker households who had savings and debts were $46 \%$ (Table 1). This fact is interest to analyze because in general, if someone has savings, they tend to use the savings as a strategy when experiencing financial difficulties. Based on the research, it is revealed that almost $32 \%$ of households in Indonesia use informal savings options that are far from formal institutional regulations because of low annual incomes and institutional distance far from their homes [14]. However, many farm worker households in Wonorejo Village actually had a debt strategy when they were being experienced by financial difficulties, even though still had savings. Additionally, data showed that farm worker households that had both savings and debts were had savings in the form of livestocks, jewelry, money savings at school and "arisan". "Arisan" as one of the terms used in simplifying concepts related to financial regulation systems, especially those found in Indonesia. "Arisan" generally contains rules and as a means of saving especially for villagers [15].

Table 1. Cross tabulation of savings and debts ownership of farm worker households in Wonorejo Village

\begin{tabular}{|c|l|l|r|r|r|}
\hline \multicolumn{2}{|c|}{} & \multicolumn{2}{|c|}{ Savings Ownership } & \multirow{2}{*}{ Total } \\
\cline { 3 - 6 } \multicolumn{2}{|c|}{$\begin{array}{c}\text { Debts } \\
\text { Ownership }\end{array}$} & Have & $\begin{array}{c}\text { Didn’t } \\
\text { Have }\end{array}$ & \\
\cline { 3 - 6 } & & Count & 35 & 8 & 43 \\
\cline { 3 - 6 } & $\begin{array}{c}\text { Didn't } \\
\text { Have }\end{array}$ & Percent. & $57,4 \%$ & $53,3 \%$ & $56,6 \%$ \\
\cline { 3 - 6 } & Percent. & $42,6 \%$ & $46,7 \%$ & $43,4 \%$ \\
\hline \multirow{3}{*}{ Total } & Count & 61 & 15 & 76 \\
\cline { 3 - 6 } & & Percent. & $100,0 \%$ & $100,0 \%$ & $100,0 \%$ \\
\hline
\end{tabular}

The fourth forms of the farm worker household's savings in Wonorejo Village have a detailed description: (1) The livestocks in Wonorejo Village were in the form on several cows or buffalos. Livestock are very important for most poor people, especially in developing countries as an economic alternative. Livestock production does not require formal education and can be turned into money when needed or has an asset function [16]. These can be sold just before the celebration of "Qurban" (moslem celebration day) in Wonorejo Village. While in the ordinary days, people who were looking for these livestocks was very little; (2) The jewelry that farm workers had only in the pieces that they (women) worn so they didn't have more; (3)
Savings in the form of money in schools was also owned by respondents who had school-age children. This savings should not be taken at any time, but there must be an agreement before; and (4) Savings in the form of "arisan" has a rotating system and can only be obtained once every few times for each person depending on the number of participants.

Additionally, savings owned by farm worker households can't be used as a last solution when the household had been experienced by low income condition. When there was an urgent financial needed, savings of livestocks and jewelry can't be directly used. These must be sold first to third parties so that it takes many time to get the money. The amount of jewelry also little. If they were being experienced by financial difficulties, some farm worker households will choose a debt strategy. Previous study showed that debts for Pakistan peoples is the strategic importance of a financing [17]. Debts used as a mechanism in reducing costs that is able to maximize access to the possibility of financial difficulties. The savings they have do not guarantee that someone is not in debt. Saving and debt holding are related to financial satisfaction [18].

\section{Conclusion}

The socio-demographic characteristics of farm worker households in Wonorejo Village are having low education and a healthy life (socio-characteristics), the majority of family heads of farm worker are male (92\%) and the average age is more than 64 years. The assets they have in the form of savings such as money, livestock, jewelry, etc. More than $50 \%$ of farm worker households have savings in the form of livestock that cannot be cashed directly to meet their needs. This causes many farm workers to have a dual financial strategy by savings and debts.

\section{References}

1. The Central Bureau of Statistics Kabupaten Situbondo. Kecamatan Banyuputih dalam Angka Tahun 2018. Situbondo: Badan Pusat Statistika Kabupaten Situbondo. (2018). In Bahasa

2. The Central Bureau of Statistics Kabupaten Situbondo. Kecamatan Banyuputih dalam Angka Tahun 2019. Situbondo: Badan Pusat Statistika Kabupaten Situbondo. (2019). In Bahasa

3. N. Hanum and Muda, I. Safuridar. Analysis of Structural Poverty Trend Among Rice Farmers in East Aceh Regency, Indonesia. Journal of Global Business \& Finance. 24 (1), pp. 71-79. (2019)

4. Balai Taman Nasional Baluran. Taman Nasional Baluran "Secuil Afrika di Jawa" (Sekilas Potensi Wisata Taman Nasional Baluran). Banyuwangi: Balai Taman Nasional Baluran. (2007). In Bahasa

5. H. S. Yunus. Metode Penelitian Wilayah Kontemporer. Yogyakarta: Pustaka Pelajar. (2010). In Bahasa 
6. C. P. Zalaquett, P. A. Mc Hatton, Ann. C-Gingras. Characteristic of Latina/o Migrant Farmworker Student Attending a Large Metropolitan University. Journal of Hispanic Higher Education. 6 (2), pp. 135-156. (2007)

7. Saggelorang, S.M.M., Vekie, A.R., Hanly, F.D.J.S. Pengaruh Pengeluaran Pemerintah di Sektor Pendidikan dan Kesehatan Terhadap Indeks Pembangunan Manusia di Sulawesi Utara. Jurnal Berkala Ilmiah EfisienSI, 15, 2 (2015). In Bahasa

8. The Central Bureau of Statistics Indonesia. Susenas 2013, 2. Jakarta. Badan Pusat Statistik Indonesia. (2014). In Bahasa

9. R. F. Putri, S. Wibirama, Sukamdi, S. R. Giyarsih. Population condition analysis of Jakarta land deformation area. IOP Conf. Series: Earth and Environmental Science 012007 148, pp. 1-10. DOI:10.1088/1755-1315/148/1/012007. (2018)

10. Rijanta, R., Hizbaron, D.R., Baiquni, M. Modal Sosial Dalam Manajemen Bencana. Yogyakarta: Gadjah Mada University Press. (2014). In Bahasa

11. Triyanti, R., Firdaus, M. Tingkat Kesejahteraan Nelayan Skala Kecil dengan Pendekatan Penghidupan Berkelanjutan di Kabupaten Indramayu. Jurnal Sosek. 11 (1), pp. 29-43. (2014). In Bahasa

12. Doda, S., Fortuzi, S. The Impsct of Saving in Personal Finance. Eur. J. Econ. Bus. 1 (2), pp. 108112. (2015)
13. Frederick, H.H., Kuratko, D.F., O'Connor, A. Entrepreneurship, 503, (2015)

14. Lidi, B. Y., Bedemo, A., Belina, M. Determinant of Saving Behavior of Farn Households in Rural Ethiopia : The Double Hurdle Approach. Journal of Economics and Sustainable Development (JEDS), 8 (19), pp. 33-42. (2017)

15. Abdullah, V. A. Arisan Sebagai Gaya Hidup (Sebuah Kritik Terhadap Masyarakat Konsumtif Perkotaan). Jurnal Komunikasi. 11 (1), pp. 17-28. (2016). In Bahasa

16. Gerber, P., Mooney, A., Dijkman, J., Tarawali, S., De Haan, C. Livestock in a Changing Landscape Volume 2. Washington: Island Press. (2010)

17. Khan, K.I., Qadeer, F., John, A., Sheeraz, M. Exixtence and Prevalence of Debt Specialization Strategy across Organizations : A Pakistani Perpective. Pakistan J. Commer. Soc. Sci. 10 (3), pp. 461-485. (2016)

18. National Endowment for Financial Education. 1 in 3 say financial life is worse than they expectit to be. [Press room news]. Retrieved from http://www.nefe.org/press-room/news/tips-forgetting-financiallyfit-in-2017.aspx. (2017, January $3)$. 